\title{
Correction to: Retrospective multicentric study of pituitary incidentalomas
}

\author{
Patricia Fainstein-Day ${ }^{1,2} \cdot$ Mirtha Guitelman $^{1} \cdot$ Rosa Artese $^{1} \cdot$ León Fiszledjer $^{1} \cdot$ Alberto Chervin $^{1} \cdot$ \\ Nicolás Marcelo Vitale ${ }^{1}$. Graciela Stalldecker ${ }^{1}$. Valeria De Miguel ${ }^{1}$. Dora Cornaló ${ }^{1}$ - Analía Alfieri ${ }^{1}$. \\ María Susana Susana Mallea-Gil ${ }^{1}$
}

Published online: 29 October 2019

๑) Springer Science+Business Media, LLC, part of Springer Nature 2019

\section{Correction to: Pituitary (2004) 7:145-148 https://doi.org/10.1007/s11102-005-1757-1}

Unfortunately one of the co-author's first name and lastname Publisher's Note Springer Nature remains neutral with regard to had been wrongly published. The correct version is Maria jurisdictional claims in published maps and institutional affiliations.

Susana Mallea Gil and not Maria Susana, and MalleaGil as published.

Moreover, there occured an error in the first and surname of corresponding author Dr. Patricia FainsteinDay. First name of the author is 'Patricia' and surname is 'Fainstein-Day'.

\section{Patricia Fainstein-Day}

patricia.fainstein@hospitalitaliano.org.ar

1 Neuroendocrinology Department of the Argentine Society of Endocrinology and Metabolism, Buenos Aires (Departamento de Neuroendocrinología de la Sociedad Argentina de Endocrinología y Metabolismo, Buenos Aires), Díaz Velez, 3889, 1200 Buenos Aires, Argentina

2 Lezica 3954, 1202 Buenos Aires, Argentina 